\title{
Issues of Small States in the Age of Globalization
}

\author{
Venera Llunji, PhD Cand. \\ University of Prishtina \\ venerallunji@hotmail.com
}

\begin{abstract}
The twentieth century has been characterized by the rise of nationalism in many parts of the world especially in the countries which lived under socialism and/or communism. Under socialism and/or communism, countries comprising of multi- ethnic groups lived in peace and cooperated and as such decreasing the possibility for any conflict. The collapse of communism and socialism in these countries of the Eastern Europe created opportunities for different forces to mobilize and capture state power mainly because these states turned into ineffective and weakened ones, as was the case with the former Yugoslavia where the ethno-national forces rose and caused ethnic strife and civil war which completely destroyed the society. The question which arises is why? Why did the destruction happen? Being a multiethnic and multinational society of different cultures, languages, history and religions, it entered into a war causing thousands of dead people, thousands of injured, destruction of properties and suffering of the people. Civil war in former Yugoslavia resulted with the partition of Yugoslavia into small independent states. But over the past few years, several changes have exposed difficulties upon these small independent states to recover fully from the harshness of the war: economic crisis, immigration, integration. IN addition, European countries have opened the doors to a new era of development, that of globalization which has been accepted mainly as the free movement of goods, services and people. Thus, this paper will deal with issues that small states face in the age of globalization.
\end{abstract}

Keywords: small states, globalization, civil war, economic crisis, immigration, integration, free movement

\section{Introduction}

In recent years the phenomenon of globalization emerged as one of the most frequently and at the same time one of the most controversial topics. There is a lack of consensus as to what globalization is, what does it challenge, what is its effect. Although it is considered as a modern phenomenon of the late 20th century and very much present in the 21 st century, globalization is not a new social and historical phenomenon because trade among nations, for example, existed even in earlier stages of human society. Nonetheless, globalization nowadays is reshaping the world in business, trade, culture, politics, media, and so on. There are $193 \mathrm{UN}$ member states. More than half of these states have been born out of transition to democracy and are classified as small states. All these small states have been created on the foundations of their history, culture, tradition, and territory. Their emerging goes hand-in-hand with all the changes and developments in the world. By saying this, defining globalization seems to be a difficult task, taking into consideration all those who support or oppose this phenomenon. Scholars do not know how to define or label globalization: as a system, a force, or a process of today's world. This mainly happens because the impact of globalization in certain states differs from the impact it might have upon other states. As such, none of the scholars have been able to prove whether globalization will improve or damage states and peoples around the world not just because there are big states and small states but simply because globalization can be beneficial for some, destructive for some and both for others. Say global and people will picture interconnectedness in a number of areas especially economy, culture and technology. Scholars, tend to see globalization either as a result of culture being the reason for economy and political developments and interconnectedness or vice versa, economy or politics being the means for such interconnectedness. Globalization also means making new spatial scales. Giddens (2007) argued "Globalization can be defined as the intensification of worldwide social relations which link distant localities in such a way that local happenings are shaped by events occurring many miles away and vice versa."(p.16). While for some globalization has made the world a better place to live in because people and resources were brought closer together, time and distance were not a barrier to move and fulfill needs and requests and desires, for some, the gap between rich and poor, between desire and needs is becoming bigger. As Cooper states:

"... while some inhabitants of our planet find themselves in an era of unprecedented 
progress in many field of human endeavors, specifically in the fields of communication

technology, scientific and technological innovation and discovery, huge economic

growth ,and improvements in health and standard of living, others find that the gap

between themselves and a life of health, prosperity and security is widening"

(Sallah and Cooper,2008:15)

Nonetheless, globalization seems to be defined as the integration of economic, social and cultural relations including political and security globalization across borders. It influences with no doubt big and small states, developed and developing states with an impact which is positive for some states in some aspects and areas but negative and difficult for some other states which makes globalization be considered uneven, because of the different reach and effect in various parts of the world; asymmetrical, because there are rich OECD countries and poor Sub-Saharan African countries. Despite the literature on globalization, it is mainly general and qualitative in nature.

This paper will focus on Kosovo and its overall aim is to provide some information on the impact of globalization on the development of Kosovo after seven years of its independence by describing its experience as a new state and comparing it with its neighboring countries.

\section{Definitions of globalization}

Since defining globalization is not easy because it tackles many spheres of people's lives, only few definitions of what globalization is are given in this paper.

Globalization is seen as a complicated process, focusing on how events, decisions and activities in one part of the world can have consequences in other parts of the world. (Lee \& Collin 2005: 4). In other words, it is a process of interaction and integration of different nations, different countries, different governments, organizations, companies having an effect on economic development, political system, culture, technology of societies around the world.

Roland Robertson, professor of sociology, in 1992 defines globalization as" ...the compression of the world and the intensification of the consciousness of the world as a whole" whereas sociologists Martin Albrow and Elizabeth King define globalization as: "...all those processes by which the peoples of the world are incorporated into a single world society".

In Global Transformations Held, McGrew, Glodblatt and Perraton,(1999),study the definition of globalization:

"Although in its simplistic sense globalization refers to the widening, deepening and speeding up of global interconnection, such a definition begs further elaboration. ... Globalization can be located on a continuum with the local, national and regional. At one end of the continuum lie social and economic relations and networks which are organized on a local and/or national basis; at the other end lie social and economic relations and networks which crystallize on the wider scale of regional and global interactions. Globalization can refer to those spatial-temporal processes of change which underpin a transformation in the organization of human affairs by linking together and expanding human activity across regions and continents. Without reference to such expansive spatial connections, there can be no clear or coherent formulation of this term. ... A satisfactory definition of globalization must capture each of these elements: extensity (stretching), intensity, velocity and impact."

Beerkens (2004) defines globalization as "The world-wide interconnectedness between nation-states which becomes supplemented by globalization as a process in which basic social arrangements (like power, culture, markets, politics, rights, values, norms, ideology, identity, citizenship, solidarity) become disembedded from their spatial context (mainly the nation-state) due to the acceleration, massification, flexibilisation, diffusion and expansion of transnational flows of people, products, finance, images and information" (p.13).

Proponents of globalization such as Robert Reich, former US Secretary of Labor, consider it as "the end of geography, the end of distance, and the absence of borders". They count several arguments in favor of globalization: free trade which will result in increased civil liberties, increased opportunity and profits for all; creation of a global village of shared values and 
understanding; increase of global cooperation, through international law and higher standards of law; increased availability of goods for average people at lower prices;

encourages investment in developing world; creates permanent jobs in developing world; increase democratic reform, because capitalism leads to democracy (former Yugoslavia used to be a socialist/communist state. New small states that emerged from the break of Yugoslavia went one step back: from a socialist country to a capitalist one, which makes the development of these small states experience difficulties as they were not prepared for such a change); increases the status of women. But globalization also has its opponents who consider that there are a number of disadvantages when it comes to globalization: "The general complaint about globalization is that it has made the rich richer while making the nonrich poorer. It is wonderful for managers and investors, but hell on workers and nature"(Panda Online, 2004); multinational corporations are accused of social injustice, unfair working conditions (including slave labor wages and poor living and working conditions), as well as a lack of concern for the environment, mismanagement of natural resources, and ecological damage; opponents say globalization makes it easier for rich companies to act with less accountability. They also claim that countries' individual cultures are becoming overpowered by Americanization; some experts think that globalization is also leading to the incursion of communicable diseases. Deadly diseases like HIVIAIDS are being spread by travelers to the remotest corners of the globe; Social welfare schemes or "safety nets" are under great pressure in developed countries because of deficits and other economic ramifications of globalization. (The Pros And Cons Of Globalization, 2010).

\section{Short history of the breakup of former Yugoslavia}

Yugoslavia was created after World War II with the unification of the six republics - Croatia, Slovenia, Serbia, Montenegro, Macedonia, and Bosnia-Herzegovina with the aim to balance the competing claims of different ethnic groups. While a degree of harmony and group interaction was achieved under Tito, underlying antagonisms and tensions remained as a very useful tool for any leader who wished to stir up nationalist sentiment, and historical bitterness has been used by all sides in the present conflict as a weapon in their quest for power. Yugoslav federation, as a state, and communist internationalism as ideology have failed to provide national equality and freedom. Tito's death in 1980, uncovered three fundamental problems: the divergent ethnic interests remained, the economy was inefficient, and the country's institutional structure was incapable of retaining Yugoslav unity. Yugoslav federation, as a state, and communist internationalism as ideology have failed to provide national equality and freedom. There regime could not overcome the national conflict because of its authoritarianism and ideologically based integration of the political community. Yugoslavia was considered a modernized country. Modernization has made considerable progress in the industrialization, technological development and education. An adequate social standard was achieved, primarily in the social sphere, and over the time a matching social structure was formed (working class, bureaucracy, professionals, middle class). (Maldini,2012:13). However, the Yugoslav modernization was not based on free market and free society. It was imposed and carried out as state policy led by the Communist Party according to an ideological basis. "There was modernization without modernity, industrial development without civic development, an ideological instead of societal integration." (Maldini,2012:13). As Maldini (2012) puts it: "There was no sufficiently independent and autonomous social segment (interest, class, gender, occupational, age, and similar groups) that could develop other public discourses and collective identities than those allowed by regime, and to be at least a substitute to civil society and alternative to Communist Party leaders" (pg.14).In other words, all segments of life were part of the state apparatus. As a result of the chauvinistic regime of Serbia upon other republics including Kosovo which was given to Serbia by its allies France and Britain after World War I, and Vojvodina, under conditions of an immediate threat to personal and collective existence caused by Greater Serbian aggression and the war for liberation, nationalism grew into a general political discourse expressing patriotism, but also political alignment towards the nation state and the government. This change resulted with the disintegration of Yugoslavia, brought the darkest years that people of former Yugoslavia could have experienced but it also brought new small states into life, in spite of serious problems and challenges that they will have to face.

In 1998 war begins in Kosovo. It was a result of growing ethnic tension and rising nationalism. Continuing repression convinced many Albanians that only armed resistance would change the situation although Rugova's policy of passive resistance succeeded in keeping Kosovo quiet during the war with Slovenia and the wars in Croatia and Bosnia during the early 1990s. However, the passive resistance was no longer a means to overcome the chauvinistic behavior of Serbs upon Kosovo Albanians. The war ended in June 1999 with the intervention of NATO forces. After the military intervention, international representatives became part of everyday Kosovo. According to the Department of State statement, 'The United 
States continues to help Kosovo become a stable, democratic, and economically viable country within Europe. Its assistance programs are designed to help achieve this goal by working in key areas of governing justly and democratically, economic growth, peace and security and investing in people. Since 1999, the United States has contributed over \$1 billion to Kosovo's development. During an international Donors' Conference on July 11, 2008 the United States renewed its commitment to support Kosovo with a pledge of over $\$ 400$ million. A significant amount of the U.S. pledge will go towards helping relieve debt Kosovo may inherit. Continued assistance will be integral to Kosovo's progress as a peaceful, democratic and economically viable state that offers equal opportunity and protections to all its citizens.'(Diplomacy in Action,). The European Union is also of great assistance to Kosovo. Their political and financial commitment to Kosovo is two-fold. The EU provides assistance to meet Kosovo's institution-building needs and socio-economic development, and it also provides a substantial contribution to the international presence in Kosovo.( http://eeas.europa.eu). The presence of international organizations, political, socio-economic and many other be it NGOs or GOs is still very active and needed for Kosovo, which declared its independence from Serbia on February 17th 2008. Nevertheless, Kosovo as as a small state welcomes the presence of international organizations because after so many years of political, economic, and cultural repression which resulted with a war, it lacks the strength and the power to stand completely on its own. The ghettoisation of Kosovo as a result of the unresolved issue of visa liberalization, the lack of political culture of the running government(s), the inability to solve inner problems such as low economic development, unemployment, corruption and organized crime, has provoked massive immigration of its people.

\section{Impacts of globalization in Kosovo}

As mentioned earlier in the paper, globalization as a phenomenon, process, force or system has its proponents who claim that it will ensure free trade, civil liberties, increased opportunity and profits for all, shared values and understanding, global cooperation through international law and higher standards of law; goods for average people at lower prices, investments, permanent jobs, democratic reform because capitalism leads to democracy, better education, developed technology, and so on. But do all states have the chance to receive all these benefits? Kosovo is a new state being recognized by around 103 UN member states and 23 EU member states. The question which arises is how can Kosovo develop and face challenges of globalization when it is not yet a fully-fledged recognized state? Can Kosovo be considered a small state? Small states are defined as those with populations of less than 1.5 million people. Kosovo has around 2 million inhabitants, majority of whom are Albanians; geographically speaking, small states are mainly landlocked, most of them are islands and are distant from major regional centers of development. Kosovo lies in the heart of Europe, it is not landlocked and it is not distant from major centers in Europe. Now, what makes Kosovo a small state is:1. Slow economic development; low scale in production, marketing, export; 2. Exposure to security risk because of unresolved issues with Serbia; 3. Limited scope and capacity for negotiating with bigger states on every issue (there are negotiations happening with Serbia and there will be negotiations regarding visa liberalization) however, Kosovo does not have the power to stand firm on its own although countries supporting the independence of Kosovo concluded that "the country had substantially implemented its independence framework, which stipulates the establishment of a functional state and focuses on minority rights and the decentralization of power".(Gashi,2013:284) Maybe Kosovo is not a small state but according to Buzan, "a weak state" as it still "suffers from economic threats, national security threats, and it also suffers from basic political and societal insecurities"(Buzan,2007:93).

\section{Economic impact of globalization in Kosovo}

Globalization is marked with increasing economic integration and growing economic interdependence between countries of the world. It brings potentials for development and wealth creation. There are however arguments that globalization has increased problems of unemployment, inequality and poverty. Although the aim of globalization is to increase the standard of living and prosper their lives, it is the developed countries that ripe the fruits of globalization by increasing export, increasing trade between other developed countries, while developing countries, although being helped with investments from developed countries created a gap between rich countries and poor ones. The same goes for Kosovo. According to the World Bank Institute, countries like Kosovo "tend to lead toward concentration of economic activities resulting in near monopolies or oligopolies (http://wbi.worldbank.org/wbi). European Commission organized in the year 2008 a donor's conference in which the Kosovo authorities presented a Mid-Term Expenditure Framework 2009-11, which estimated a 
funding gap of some $€ 1.1$ billion for Kosovo's socio-economic development over the coming three years. A total of $€ 1.2$ billion was pledged by the international community, including some $€ 100$ million for a stabilization fund for contingent liabilities. Kosovo has implemented initial reforms to establish a fully functioning market economy but the weak rule of law, a large informal economy and an underdeveloped policy framework continue to hinder socio-economic growth. The business climate in Kosovo is hindered by limited access to finance, unreliable energy supply, unfair competition and corruption. Kosovo's enterprise sector is dominated by small and micro-enterprises; retail trade continues to be the dominant sector. The trade deficit is large, with a deficit of 33.9\% 5 of GDP and a ratio of imports to exports of some 9:1. Kosovo's main trading partners are the EU, Albania, Serbia, the former Yugoslav Republic of Macedonia and Turkey. Currently, about $90 \%$ of exports consist of raw materials. Moreover, economic statistics (central accounts in particular) are extremely weak, making a comprehensive assessment of the economic situation difficult. GDP per capita is EUR 2794 in 2013.(Eurostat). Kosovo joined the World Bank and the International Monetary Fund in 2009 and has been a full member of the European Bank for Reconstruction and Development since December 2012. In June 2013, Kosovo signed a framework agreement with the EIB. It became a member of the Council of Europe Development Bank in November 2013.( Indicative Strategy Paper For Kosovo* (2014-2020)). Though the international organizations and organisms have great influence on helping the development of the economy of Kosovo, there are still a number of obstacles that Kosovo faces. As such, globalization may be seen as a burden on the shoulders of a state like Kosovo even though quite a number of Kosovo's population live abroad and thus contribute to remittances. However, globalization can be diverse in different parts of the world and as such creates a gap between countries by making some richer and some poorer.

\section{Political impact of globalization in Kosovo}

Democracy is seen as the ultimate form of political stability by the world. Values of freedom, liberty, tolerance are considered the key prerequisites to a political stability. Under globalization, politics can take place above the state through political integration schemes such as the European Union and through intergovernmental organizations such as the International Monetary Fund, the World Bank and the World Trade Organization. Political activity can also transcend national borders through global movements and NGOs. Civil society organizations act globally by forming alliances with organizations in other countries, using global communications systems, and lobbying international organizations and other actors directly, instead of working through their national governments.(Global Policy Forum)

In 1999, the conflict in Kosovo intensified, resulting in hundreds of thousands of refugees leaving the country (the province, at that time). The UN Security Council passed a series of resolutions-numbers 1160, 1199, and 1203-addressing the unfolding situation in Kosovo. UN sponsored peace negotiations in Rambouillet.

Under Chapter VII, Article 42 of the UN Charter, the provision often cited as justification for humanitarian intervention; the UN Security Council can authorize the use of force when such actions are "necessary to maintain or restore international peace and security"(Charter of the United Nations: Chapter VII.). The Security Council sought to invoke this provision to take a more active role in Kosovo, but Russia and China vetoed the authorization of force.

As a result, NATO decided to intervene without UN sanction and launched a campaign of air strikes against Serbian forces. The action led to the withdrawal of Serbian troops from Kosovo (Terry, 2004)(Dietrich, 2003). From 1999 until 2008, Kosovo was administered by the United Nations Interim Administrative Mission in Kosovo (UNMIK). In February 2008, Kosovo declared its independence. Again the international organisms played their part. The International Court of Justice gave its Advisory Opinion on the question of the Accordance with international law of the unilateral declaration of independence in respect of Kosovo. Serbia still continues to deny recognition. Ten rounds of talks were held at the European External Action Service office in Brussels. Normalization of relations with neighboring states is a key precondition for states wishing to join the EU. The agreement was supported by the European Union, NATO, the OSCE, and the United Nations. This shows that political activity increasingly takes place at the global level.

\section{Conclusion}

Globalization has influenced many nations in various ways considering it as a process which shapes nations in different areas, like economy, politics, technology, education, and so on. As globalization has progressed, living conditions have 
improved significantly in virtually all countries. However, the strongest gains have been made by the advanced countries and only some of the developing countries. No country, least of all the poorest, can afford to remain isolated from the world economy and political development. No country can afford to remain isolated from the benefits of education and the development of technology. Every country should seek to reduce poverty, to increase wealth, to nurture its culture and share it with others, use the advantages of developed technology and improve his/her well-being. Strengthening the international financial system, through trade, and through aid developed countries can help the poorest countries integrate into the world economy, grow more rapidly, and reduce poverty. That is the way to ensure all people in all countries have access to the benefits of globalization.

\section{References}

[1] Buzan,B.(2007): People, States \& Fear: An agenda for international security studies in the post-cold war era. ECPR Press.

[2] Held,D.and McGrew,A.,Glodblatt,D. and Perraton,J.(1999), Global transformations:Politics,Economics and Culture, Polity Press, Cambridge. Retrieved from: http://www.polity.co.uk/global/globalization-oxford.asp

[3] Indicative Strategy Paper For Kosovo* (2014-2020)

[4] Gashi,K.(2013) Nations in Transit,p.284

[5] Global Policy Forum. Retrieved from: https://www.globalpolicy.org/globalization/globalization-of-politics.html

[6] Maldin,Pi(2012): Nationalism in Croatian Transition to Democracy. CONTEMPORARY issues, Vol. 5, No. 1. Political science research centre at: www.cpi.hr

[7] Robertson, R.(1992). Globalization : social theory and global culture(Reprint. ed.). London: Sage. ISBN 0803981872.

[8] Sallah, M. and Cooper, S. (2008) Global Youth Work: Taking it Personally, Leicester, NYA.

[9] The Cons of Globalization, An Essay Against Globalization, Panda Online, Dec 25, 2004

[10] The Pros And Cons Of Globalization. Retrieved from: (http://www.inddist.com/articles/2010/12/pros-and-consglobalization) 